УДК $579.695+537.31+[547-386+546.72]$

\author{
O.M. Vasyliv, O.D. Maslovska, S.O. Hnatush, O.I. Bilyy, Ya.P. Ferensovych \\ Ivan Franko National University of Lviv, 1, Universytetska Str., Lviv, 79000, Ukraine; \\ tel.: (0322) 3941 53, e-mail: oresta.vasyliv@gmail.com
}

\title{
ELECTRIC CURRENT GENERATION BY DESULFUROMONAS ACETOXIDANS IMV B-7384 WHILE FERRIC CITRATE, FUCHSINE AND METHYLENE BLUE APPLICATION
}

\begin{abstract}
Aim: to investigate the process of exoelectrogenesis performed by Desulfuromonas acetoxidans IMV B-7384 in a microbial fuel cell (MFC) under the presence of exogenous electron mediators (fuchsine, methylene blue) and $\mathrm{Fe}^{3+}$. Methods: bioelectrochemical analysis, cultivation in the MFC. Results: The interrelation between Fe (III)-reduction and exoelectrogenesis performed by D. acetoxidans IMVB-7384 in the MFC has been determined. Under the influence of ferric citrate, fuchsine and methylene blue power density decreased in comparison with addition of sodium (III) citrate (control). Conclusions. Ferric citrate, fuchsine and methylene blue serve as the exogenous electron acceptors while application of D. acetoxidans IMV B-7384 as the anode biocatalyst in the MFC that causing decrease of power density at these conditions.
\end{abstract}

Key words: D. acetoxidans IMV B-7384, electric current generation, microbial fuel cell, ferric citrate, exogenous electron mediators.

Nowadays there is increasing scientific and commercial interest to one type of bioelectrochemical systems - microbial fuel cell (MFC). The essential of MFC technology is usage of an unique type of electrogenic bacterial strains that can biooxidize organic matter to produce electrons in their central metabolism and transfer part of electrons extracellularly to an external electrode $[6,11]$.

One of the main challenges of MFC technology is finding the most efficient electrogenic bacterial strain in term of electricity generation while biooxidation of organic matter.

Desulfuromonas acetoxidans IMV B-7384 is promising non sufficiently investigated exoelectrogenic anaerobic bacterium. It was shown that separate application of fumaric, succinic, pyruvic, citric, and malic acids into the anode chamber of MFC caused increase of maximal generated power density from $2.14 \pm 0.19 \mathrm{~mW} / \mathrm{m}^{2}$ to $10.07 \pm 0.17 \mathrm{~mW} / \mathrm{m}^{2}$ while presence of $D$. acetoxidans IMV B- 7384 as the anode biocatalyst [9]. This bacterium possesses several advantages for being applied as the anode biocatalyst in MFC. 
D. acetoxidans IMV B-7384 cell size is $0.4-0.8 \mu \mathrm{m} \times 1-4 \mu \mathrm{m}$ [3]. Due to comparably small size it could be highly beneficial while application of porous anode material because of the possibility of cell complete cover of electrode area. This particularity could significantly improves the effectiveness of electrode area usage.

It was determined that $D$. acetoxidans can oxidize elemental sulfur to sulfite and sulfate with an electrode serving as an electron acceptor, and cause $\mathrm{S}^{0}$-reduction with $\mathrm{H}_{2} \mathrm{~S}$ generation as well $[3,10]$. Elemental sulfur can accumulate on anode surface because of abiotic oxidation of sulfide. It reveals the possibility of continuous simultaneous carrying of opposite stages of sulfur cycle in the anode chamber of MFC by activity of only one genus of bacterium. Hence simultaneous sulfur redox reactions supported by $D$. acetoxidans doubles the electron transfer to the electrode it can lead to enhancement of the effectiveness of MFC power output.

It was shown that MFC design can be easily integrated into the system of wastewater treatment. D. acetoxidans IMV B-7384 was determined to possess selective resistance to $\mathrm{Cu}^{2+}, \mathrm{Fe}^{2+}, \mathrm{Fe}^{3+}, \mathrm{Ni}^{2+}, \mathrm{Mn}^{2+}$ and $\mathrm{Co}^{2+}$ in the range of $0.5-2.5 \mathrm{mM}$ [3]. The activity of superoxide dismutase, catalase and glutathione synthesis as a part of antioxidative defense system of $D$. acetoxidans IMV B-7384 were observed in spite of their obligate anaerobic metabolism under the influence of transition metal ions [3]. The obtained results show that investigated bacteria possess specific mechanisms of rapid defense against toxic influence of high concentrations of various metal ions. Therefore its application as the anode biocatalyst in MFC that contains wastewater as anolyte can be highly beneficial. In previous studies it was determined that variety of chemicals could facilitate the shuttling of electrons from inside the cell to the electrodes outside the cell. These exogenous mediators include e.g. neutral red [7], anthraquinone-2-6-disulfonate (AQDS), thionin, potassium ferricyanide [4], methyl viologen, and others [5, 8]. It was crucial to investigate the influence of possible electron shutters, such as fuchsine and methylene blue on $D$. acetoxidans IMV B-7384 ability to generate electric current in the constructed MFC. Since D. acetoxidans IMV B-7384 is capable to Fe (III) - reduction it was important to determine whether there exist dependence between the extent of exoelectrogenesis and ferric iron reduction. Therefore the aim of work was to determine the influence of $\mathrm{Fe}^{3+}$, fuchsine and methylene blue on D. acetoxidans IMV B-7384 capability to generate electric current.

\section{Materials and methods}

D. acetoxidans IMV B-7384 is deposited in the Ukrainian Collection of Microorganisms at the D.K. Zabolotny Institute of Microbiology and Virology NAS of Ukraine [1]. Bacteria were cultivated in the anode chamber of constructed MFC in the modified Postgaite $\mathrm{C}$ medium under the anaerobic conditions and temperature $25-28{ }^{\circ} \mathrm{C}$ for twenty days. $42 \mathrm{mM}$ sodium (III) citrate $\left(\mathrm{Na}_{3} \mathrm{C}_{6} \mathrm{H}_{5} \mathrm{O}_{7}\right)$ has been added as the sole source of organic Carbon. $10 \mathrm{mM}$ ferric citrate $\left(\mathrm{C}_{6} \mathrm{H}_{5} \mathrm{FeO}_{7}\right)$ was applied as the donor of $\mathrm{Fe}^{3+} .0 .015 \mathrm{mM}$ fuchsine $\left(\mathrm{C}_{20} \mathrm{H}_{20} \mathrm{~N}_{3} \times \mathrm{HCl}\right)$ and $0.015 \mathrm{mM}$ methylene blue $\left(\mathrm{C}_{16} \mathrm{H}_{18} \mathrm{ClN}_{3} \mathrm{~S}\right)$ have been added separately as the exogenous electron mediators. 
$0.1 \% \mathrm{KMnO}_{4}$ solution and bacterial suspension with $0.30 \pm 0.05 \mathrm{~g}$ of dry cell weight per liter initial biomass served as catholyte and anolyte, respectively. Anode and cathode chambers with 0.31 volume were separated by proton-exchange membrane (Millipore) with surface area of $2.5 \mathrm{~cm}^{2}$. Graphite rods with the surface area of $130 \mathrm{~cm}^{2}$ were applied as electrodes.Electric current and voltage generation in the constructed MFC were determined from the measured voltage drop across the resistor $(1.8 \mathrm{k} \Omega)$ by multimeter DT-830C. Power generation in the constructed MFC was observed under the presence of sodium (III) citrate in concentration $42 \mathrm{mM}$ and separate application of $10 \mathrm{mM}$ ferric citrate, $0.015 \mathrm{mM}$ fuchsine, and $0.015 \mathrm{mM}$ methylene blue. The crucial statistical indices were calculated on the basis of obtained data, such as arithmetical mean (M) and standard deviation of arithmetical mean (m). Student coefficient was calculated for the estimation of validity of difference between the statistical characteristics of two alternative complexes of data. The difference was claimed to be valid under the index of validity $\mathrm{P}>0.95$. Statistical calculation of the results was conducted by Origin and Excel software.

\section{Results and discussion}

Power generation by $D$. acetoxidans IMV B-7384 in the MFC while presence of $10 \mathrm{mM}$ ferric citrate and $32 \mathrm{mM}$ sodium (III) citrate and without addition of $\mathrm{Fe}^{3+}$ into the growth medium has been determined. D. acetoxidans IMV B-7384 has been cultivated for twenty days in the MFC under the presence of $42 \mathrm{mM}$ sodium (III) citrate as the electron donor (fig. 1). Power density increased up to $7.21 \pm 0.32 \mathrm{~mW} /$ $\mathrm{m}^{2}$ at these conditions on the 40th hour of cultivation, although further increase of cultivation time caused its slight diminishing. It could be a result of partial reduction of $\mathrm{KMnO}_{4}$ in the cathode chamber of MFC because of intensive bacterial exoelectrogenesis.

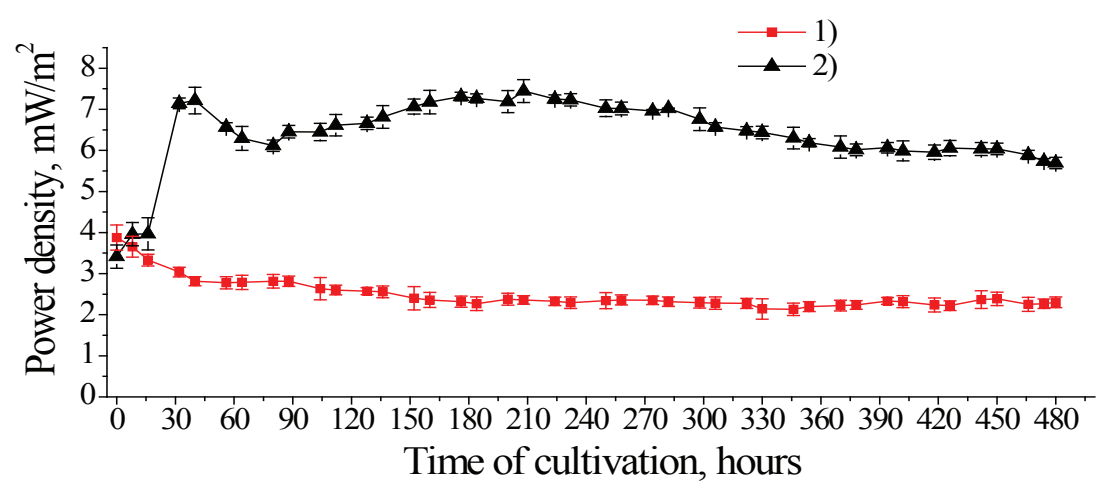

Fig. 1. Power density in the MFC during twenty days of $D$. acetoxidans IMV B-7384 growth under separate addition of 1 ) $10 \mathrm{mM}$ ferric citrate $\& 32 \mathrm{mM}$ sodium (III) citrate, and 2) $42 \mathrm{mM}$ sodium (III) citrate

Catholyte substitution by fresh $\mathrm{KMnO}_{4}$ solution caused further stabile power generation. Maximal power density equaled $7.44 \pm 0.28 \mathrm{~mW} / \mathrm{m}^{2}$ on the 208 hour of 
bacterial cultivation at these conditions. On the 480 hour its value increased by $42 \%$ in comparison with the initial value $\left(3.41 \pm 0.28 \mathrm{~mW} / \mathrm{m}^{2}\right)$. At the presence of $10 \mathrm{mM}$ ferric citrate and $32 \mathrm{mM}$ sodium (III) citrate power density decreased by $39 \%$ and $41 \%$ respectively by 208 and 480 hours of bacteria cultivation in comparison with the initial value $\left(3.88 \pm 0.31 \mathrm{~mW} / \mathrm{m}^{2}\right)$ (fig 1). Possibly, at these conditions released electrons because of organic matter oxidation were transferred to $\mathrm{Fe}^{3+}$ as the additional electron acceptor in the anode chamber of MFC. Consequently the output of electric current decreased since the amount of electrons that could reach the anode surface diminished in comparison with the separate application of $42 \mathrm{mM}$ sodium (III) citrate. It was established that $D$. acetoxidans IMV B-7384 growth is partly inhibited at the presence of $10 \mathrm{mM}$ ferric citrate [2]. Electrons are transferred to the anode surface while bacterial oxidation of organic Carbon source in MFC if additional acceptor is not present. Obviously, released electrons because of organic matter oxidation cause $\mathrm{Fe}^{3+}$-reduction and respectively inhibition of exoelectrogenesis at the presence of Ferric ions in the growth medium. Carried out research confirms that D. acetoxidans IMV B-7384 could exogenously transfer electrons to electrode surface in MFC and perform $\mathrm{Fe}^{3+}$-reduction at the presence of $\mathrm{Fe}$ (III) as the additional electron acceptor.

Exoelectrogenic activity of $D$. acetoxidans IMV B-7384 in MFC while presence of $0.015 \mathrm{mM}$ fuchsine (F), $0.015 \mathrm{mM}$ methylene blue (MB) and $42 \mathrm{mM}$ sodium (III) citrate has been investigated. The maximal power density equaled to $2.40 \pm 0.21$ $\mathrm{mW} / \mathrm{m}^{2}$ on the 16 hour and $3.11 \pm 0.11 \mathrm{~mW} / \mathrm{m}^{2}$ on the 32 hour at the presence of MB and F (fig. 2).

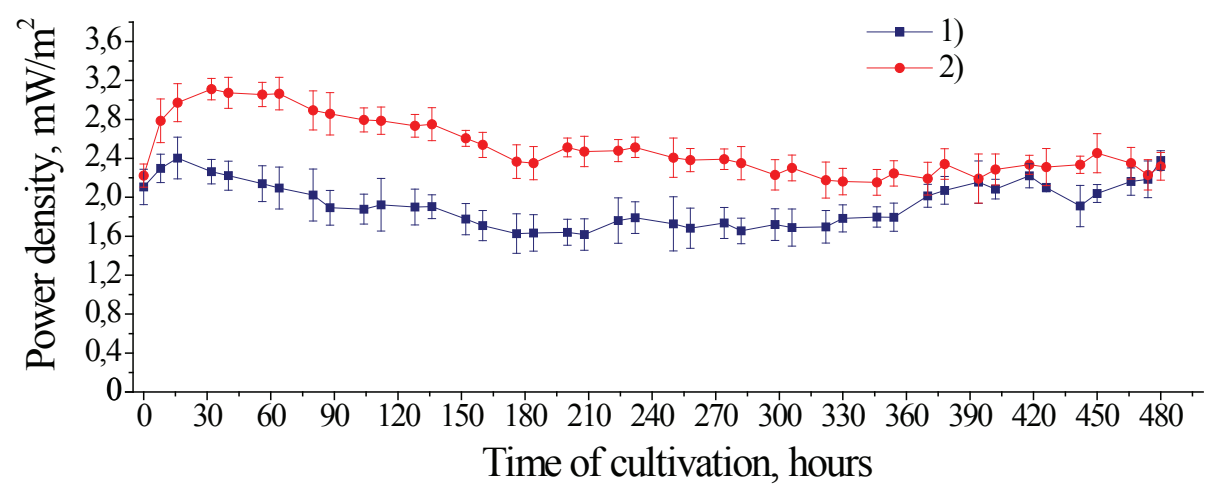

Fig. 2. Power density in MFC during twenty days of D. acetoxidans IMV B-7384 growth under presence of $42 \mathrm{mM}$ sodium (III) citrate and addition of 1) $0.015 \mathrm{mM}$ methylene blue, 2) $0.015 \mathrm{mM}$ fuchsine

Generated power density decreased in comparison with the separate application of $42 \mathrm{mM}$ sodium (III) citrate (control (fig 1, curve 2)). It was lower by 3.1 and 2.4 times respectively at the presence of $\mathrm{MB}$ and $\mathrm{F}$ in comparison with the highest obtained value in control $\left(7.44 \pm 0.28 \mathrm{~mW} / \mathrm{m}^{2}\right)$. Presumably F and MB accept released electrons as electron mediators, although their presence in the anode chamber does not facilitate electron transfer to the anode surface. Possibly, it serves as the electron 
shutters for supporting electron transfer in other metabolic processes of $D$. acetoxidans IMV B-7384.

Therefore electrons are transferred to the anode surface while bacterial oxidation of organic Carbon source in the constructed MFC if additional electron acceptor is not present. Obviously, released electrons because of organic matter oxidation cause $\mathrm{Fe}^{3+}$-reduction and respectively inhibition of exoelectrogenesis at the presence of Ferric ions in the growth medium. Presence of fuchsine and methylene blue does not facilitate electron transfer to the anode surface in MFC because of decreased power density, generated by investigated bacteria in comparison with the control. Possibly these compounds accept part of the released electrons while exoelectrogenesis performed by $D$. acetoxidans IMV B-7384. The next involvement of transferred electrons by $\mathrm{F}$ and $\mathrm{MB}$ into bacterial transport and metabolic processes requires further studying.

As the conclusion, the interconnection between $\mathrm{Fe}^{3+}$-reduction and exoelectrogenesis performed by $D$. acetoxidans IMV B-7384 in the constructed MFC has been determined. Presence of $\mathrm{Fe}^{3+}$, methylene blue and fuchsine in the growth medium of D. acetoxidans IMV B-7384 partly inhibits electricity generation in MFC compared to application of sole sodium (III) citrate as the Carbon source.

\title{
О.М. Василів, О.Д. Масловська, С.О. Гнатуш, О.І. Білий, Я.П. Ференсович
}

Львівський національний університет імені Івана Франка, вул. Університетська, 1, Львів, 79000, Україна, тел.: (0322) 3941 53, e-mail: oresta.vasyliv@gmail.com

\section{ГЕНЕРУВАННЯ ЕЛЕКТРИЧНОГО СТРУМУ DESULFUROMONAS ACETOXIDANS IMV B-7384 ЗА ВНЕСЕННЯ ФЕРУМ (III) ЦИТРАТУ, ФУКСИНУ І МЕТИЛЕНОВОГО СИНЬОГО}

\begin{abstract}
Реферат
Mета: дослідити процес екзоелектрогененезу, щзо здійснюється Desulfuromonas acetoxidans IMV B-7384 у мікробному паливному елементі (MПE) за наявності екзогенних переносників електронів та $\mathrm{Fe}^{3+}$. Методи: біоелектрохімічний аналіз, культивування у МПЕ. Результати. Встановлено взаємозв'язок між $\mathrm{Fe}$ (III)-редукиією та екзоелектронезом, щуо здійснюються D. acetoxidans IMV B-7384. За впливу ферум (III) изитрату, фуксину та метиленового синього густина потужності зменшувалась в порівнянні із внесенням натрій ичитрату (контроль). Висновки. Ферум (III) цитрат, фуксин та метиленовий синій виконують роль екзогенних акцепторів електронів за наявності D. acetoxidans IMV B-7384 як анодних біокаталізаторів у МПЕ, щзо призводить до зменшення густини потужності за наведених умов.
\end{abstract}

Ключові слова: D. acetoxidans IMB B-7384, генерування електричного струму, мікробний паливний елемент, ферум (III) циттрат, екзогенні медіатори електронів. 


\title{
О.М. Василив, О.Д. Масловская, С.А. Гнатуш, А.И. Билый,
} Я.П. Ференсович

Львовский национальный университет имени Ивана Франко, ул. Университетская, 1, Львов, 79000, Украина, тел.: (0322) 3941 53, e-mail: oresta.vasyliv@gmail.com

\section{ГЕНЕРИРОВАНИЕ ЭЛЕКТРИЧЕСКОГО ТОКА DESULFUROMONAS ACETOXIDANS IMV B-7384 ПРИ ВНЕСЕНИИ ФЕРРУМ (III) ЦИТРАТА, ФУКСИНА И МЕТИЛЕНОВОГО СИНЕГО}

\begin{abstract}
Реферат
Цель: исследовать процесс экзоэлектрогененеза, осуществляемый Desulfuromonas acetoxidans IMV B-7384 в микробном топливном элементе (МТЭ) при наличии экзогенных переносчиков электронов и Fе ${ }^{3+}$. Методы: биоэлектрохимический анализ, культивирование в МТЭ. Результаты. Установлена взаимосвязь между $\mathrm{Fe}$ (III)-редукиией и экзоэлектрогенезом, осуществляемыми D. acetoxidans IMV B-7384. При воздействии феррум (III) цчитрата, фуксина и метиленового синего плотность мощности уменьшалась, по сравнению с внесением натрий циитрата (контроль). Выводы. Феррум (III) ичитрат, фуксин и метиленовый синий выполняют роль экзогенных акиепторов электронов при наличии D. acetoxidans IMV B-7384 как анодных биокатализаторов в МТЭ, что приводит к уменьшению плотности мощности при этих условиях.
\end{abstract}

Ключевые слова: D. acetoxidans IMB B-7384, генерирование електрического тока, микробный топливный элемент, феррум (III) ичитрат, экзогенные медиатори електронов.

\section{Список використаної літератури}

1. Гудзь С.П., Гнатуш С.О., Мороз О.М., Перетятко Т.Б., Василів О.М. Свідоцтво про депонування штаму бактерій Desulfuromonas acetoxidans Ya2006 з наданням реєстраційного номеру IMB B-7384 // Депозитарій Інституту мікробіології і вірусології ім. Д. К. Заболотного НАН України. - К., 2013. 3 с. - Деп. в IMB 10.04.13.

2. Масловська О.Д., Гнатуш С.О. Вплив ферум (III) цитрату на АТФгідролази Desulfuromonas acetoxidans IMB B-7384 // Вісник Дніпропетровського університету. - 2013. - 21, № 1. - Р. 3-8.

3. Bilyy O.I., Vasyliv O.M., Hnatush S.O. Technology and application of microbial fuel cells. - Croatia.: InTech, 2014. - P. 33-54.

4. Bond D.R., Holmes D.E., Tender L.M., Lovley D.R. Electrode-reducing microorganisms that harvest energy from marine sediments // Science. - 2002. -295 , № 5554. - P. 483-485.

5. Logan B.E. Extracting hydrogen and electricity from renewable resources // Environ. Sci. Technol. - 2004. - 38, № 9. - P. 160A-167A. 
6. Logan B.E. Microbial fuel cells. - NJ.: John Wiley \& Sons, 2007. - 213 p.

7. Park D.H., Laivenieks M., Guettler M.V., Jain M.K., Zeikus J.G. Microbial utilization of electrically reduced neutral red as the sole electron donor for growth and metabolite production // Appl. Environ. Microbiol. - 1999. - 65, № 7. P. 2912-2917.

8. Rabaey K., Boon N., Hofte M., Verstraete W. Microbial phenazine production enhances electron transfer in biofuel cells // Environ. Sci. Technol. - 2005. - 39, № 9. - P. 3401-3408.

9. Vasyliv O.M., Maslovska O.D., Ferensovych Ya.P., Bilyy O.I., Hnatush S.O. Interconnection between tricarboxylic acid cycle and energy generation in microbial fuel cell performed by Desulfuromonas acetoxidans IMV B-7384 // Proc. SPIE. 2015. - Vol. 9493. - P. 94930J1-94930J7.

10. Zhang T., Bain T.S., Barlett M.A., Dar S.A., Snoeyenbos-West O.L., Nevin K.P., Lovley D.R. Sulfur oxidation to sulfate coupled with electron transfer to electrodes by Desulfuromonas strain TZ1 // Microbiology. - 2014. - 160, № 1. - P. 123-129.

11. Zhuwei D., Haoran L., Tingyue G. A state of the art review on microbial fuel cells: A promising technology for wastewater treatment and bioenergy // Biotechnology Advances. - 2007. - 25. - P. 464-482.

\section{References}

1. Gudz SP, Hnatush SO, Moroz OM, Peretiatko TB, Vasyliv OM. Certificate of deposition of bacterium Desulfuromonas acetoxidans Ya-2006 strain in the Depository of D.K. Zabolotny Institute of Microbiology and Virology of the NAS of Ukraine with appropriation of registration number IMV B-7384. - D.K. Zabolotny Institute of Microbiology and Virology, 10.04.2013:3.

2. Maslovska OD, Hnatush SO. The influence of ferric (III) citrate on ATPhydrolases of Desulfuromonas acetoxidans IMV B-7384. Visnyk of Dnipropetrovsk Uiversity. 2013;(21(1)):3-8.

3. Bilyy OI, Vasyliv OM, Hnatush SO. Technology and application of microbial fuel cells. InTech, Croatia, 2014. 96 p.

4. Bond DR, Holmes DE, Tender LM, Lovley DR. Electrode-reducing microorganisms that harvest energy from marine sediments. Science. 2002;(295(5554)):483-485.

5. Logan $B E$. Extracting hydrogen and electricity from renewable resources. Environ. Sci. Technol. 2004;(38 (9)):160A-167A.

6. Logan BE Microbial fuel cells. John Wiley \& Sons, NJ, 2007. 213 p.

7. Park DH, Laivenieks M, Guettler MV, Jain MK, Zeikus JG. Microbial utilization of electrically reduced neutral red as the sole electron donor for growth and metabolite production. Appl. Environ. Microbiol. 1999;(65 (7)):2912-2917.

8. Rabaey K, Boon N, Hofte M, Verstraete $W$. Microbial phenazine production enhances electron transfer in biofuel cells. Environ. Sci. Technol. 2005;(39 (9)): 3401-3408. 
9. Vasyliv OM, Maslovska OD, Ferensovych YaP, Bilyy OI, Hnatush SO. Interconnection between tricarboxylic acid cycle and energy generation in microbial fuel cell performed by Desulfuromonas acetoxidans IMV B-7384. Proc. SPIE. 2015;(9493):94930J1-94930J7.

10. Zhang T, Bain TS, Barlett MA, Dar SA, Snoeyenbos-West OL, Nevin KP, Lovley $D R$. Sulfur oxidation to sulfate coupled with electron transfer to electrodes by Desulfuromonas strain TZ1. Microbiology. 2014;(160 (1)):123-129.

11. Zhuwei D, Haoran L, Tingyue G. A state of the art review on microbial fuel cells: A promising technology for wastewater treatment and bioenergy. Biotechnology Advances. 2007;(25):464-482.

Стаття надійшла до редакції 09.11.2016 р. 